\title{
Integration of Mineral Fertilizer and Poultry Manure for Improving Soil Health and Maize Growth under Calcareous Soil Environment
}

\author{
Muhammad Fiyyaz ${ }^{1}$, Ghulam Sarwar ${ }^{1 *}$, Noor-Us-Sabah ${ }^{1}$, Mukkram Ali Tahir ${ }^{1}$, Muhammad Aftab ${ }^{2}$, \\ Muhammad Zeeshan Manzoor ${ }^{1}$, Sarfraz Hussain ${ }^{3}$, Ayesha Zafar ${ }^{1}$, Imran Shehzad $^{1}$ and Aneela Riaz ${ }^{4}$
}

${ }^{1}$ Department of Soil and Environmental Sciences, College of Agriculture, University of Sargodha, Pakistan; ${ }^{2}$ Institute of Soil Chemistry and Environmental Sciences, AARI, Faisalabad, Pakistan; ${ }^{3}$ Institute of Soil Chemistry and Environmental Sciences, Kala Shah Kaku, Pakistan; ${ }^{4}$ Soil Bacteriology Section, AARI, Faisalabad, Pakistan.

Abstract | Pakistani soils are deficient in organic matter. Organic matter in the soil affects soil properties and processes. The adequate carbon level of the soil is $1.29 \%$ but in Pakistani soils carbon is less than the adequate level because of high temperature and low rainfall. Different sources of organic matters such as farm yard manure, poultry waste, rice husk etc. can increase productiveness of soil. Combined usage of poultry waste material and chemical fertilizer improved maize growth and health of soil. This experiment comprised of 11 treatments applied under completely randomized design like, $\mathrm{T} 1=$ chemical fertilizers at recommended rate, $\mathrm{T} 2=$ chemical fertilizers at half recommended rate, $\mathrm{T} 3=$ waste of poultry at the rate of 5 ton/ha, $\mathrm{T} 4=$ waste of poultry at the rate of $7.5 \mathrm{ton} / \mathrm{ha}, \mathrm{T} 5=$ waste of poultry at the rate of $10 \mathrm{ton} / \mathrm{ha}, \mathrm{T} 6=\mathrm{T} 1+\mathrm{T} 3, \mathrm{~T} 7=\mathrm{T} 1+$ $\mathrm{T} 4, \mathrm{~T} 8=\mathrm{T} 1+\mathrm{T} 5, \mathrm{~T} 9=\mathrm{T} 2+\mathrm{T} 3, \mathrm{~T} 10=\mathrm{T} 2+\mathrm{T} 4$ and $\mathrm{T} 11=\mathrm{T} 2+\mathrm{T} 5$. At maturity and different agronomic and yield parameters were recorded before harvesting maize plants. Laboratory analysis for collected soil samples was carried out. Data were statistically analyzed. Results indicated that treatment (T8) produce maximum plant height $(115.0 \mathrm{~cm})$, biomass $(64.34 \mathrm{~g})$ and root length $(27.083 \mathrm{~cm})$ of maize. Organic matter content $(1.78 \%)$, phosphorus $(16.67 \mathrm{ppm})$ and potassium $(213.0 \mathrm{ppm})$ concentration in soil was also increased in this treatment.

Received | March 14, 2021; Accepted | March 28, 2021; Published | June 20, 2021

*Correspondence | Ghulam Sarwar, Department of Soil and Environmental Sciences, College of Agriculture, University of Sargodha, Pakistan; Email: ghulam.sarwar@uos.edu.pk

Citation | Fiyyaz, M., G. Sarwar, N.U. Sabah, M.A. Tahir, M. Aftab, M.Z. Manzoor, S. Hussain, A. Zafar, I. Shehzad and A. Riaz. 2021. Integration of mineral fertilizer and poultry manure for improving soil health and maize growth under calcareous soil environment. Pakistan Journal of Agricultural Research, 34(3): 495-500.

DOI | https://dx.doi.org/10.17582/journal.pjar/2021/34.3.495.500

Keywords | Maize, Poultry manure, Mineral fertilizer, Yield parameters, Soil health parameters

\section{Introduction}

$\mathrm{I}$ n Pakistan, maize is the most significant crop next rice and wheat. Maize is called "king of grain crops". Its average production is $3428 \mathrm{~kg} \mathrm{ha} \mathrm{ha}^{-1}$ (Anonymous, 2008). Along with grains it is also grown for fodder (Khaliq et al., 2004). In Khyber Pakhtunkhwa (KPK) it is cultivated in $55.01 \%$ of the total area with $63.01 \%$ of yield production whereas in Punjab30-35\% yield is achieved from $38 \%$ of the total area. In Sindh and Baluchistan, it is produced with $3 \%$ and $5 \%$ yield of the total cultivated area (GOP, 2015). Maize production in 2010 in Pakistan was 36581000 tons from 9 lac 81 thousand ha. Maize grains are the source of minerals, vitamins and ashes. It contains fats $(5.8 \%)$, proteins (10\%), starch (72\%), sugar (3\%) and burning ash (1.7\%). It is used for the production of cosmetics, flakes, syrup, alcohol, starch and fats. The origin of maize plant is exotic South USA (Chaudhary et al., 2014). Pakistani soils are 
degraded day by day due to inadequate management and fertilizer application. These soils are deficient in organic matter due to aridity factor of area. Mostly Pakistani soils have less than $1 \%$ organic matter. Imbalanced fertilizers application adversely affects plant growth and efficiency. Plant response to applied fertilizer depends on nutrient status of the soil. Fertilizer imbalance is associated with a number of factors like unavailability at proper time and higher charge. Improper fertilizer application also pollute atmosphere (Oad et al., 2004; Prabhu et al., 2003). Organic manure enhances soil fertility and increase plant growth as a supplement of manures due to provision of various nutrient and chelating effect on cations by normal acids (Mohanty et al., 2006). They improve the nutrient position of the soil that led to increase availability of nutrients in soil. People prefer goods obtained by organic farming because of their purity, uncontaminated and less adversely affective to health (Gorttappech et al., 2000).

Addition of various organic amendments improved the maximum height of rice-wheat. The use of compost proved to be superior to that of Sesbania and Farm Yard Manure (FYM) green manure. This tendency to increase the height of the plant increased when the chemical fertilizer was combined with these organic materials. The combination of fertilizers and compost at the highest rate (10 ton/ha) was the most successful treatment (Sarwar, 2005). Similarly, combining both amounts of compost + chemical fertilizers caused maximum agglomeration in ricewheat plants compared to FYM and Sesbania. Using FYM proved to be superior to control and led to a substantial rise in the number of rice-wheat crops growers. A comparison of compost and fertilizer proved the superiority of compost over chemical fertilizer in this regard, but combination of these proved to be more successful than using compost alone (Sarwar et al., 2007).

Combined usage of carbon-based manures like waste cow dung, poultry manure, residues of harvested crops and green manure crops with mineral fertilizer is the best way to manage nutrients in soil (Antil, 2012). This also improves soil fertility, conserve soil and reduce environmental pollution. Considerable usage of different nutritional sources proved important for increasing demand of crop production and sustainable agriculture (Korsaeth et al., 2002). An increase in rice and wheat production was achieved when mineral fertilizers was coupled with different sources of organic materials (Sarwar et al., 2020).

\section{Materials and Methods}

A research trail was conducted in pots to determine combined outcome of mineral fertilizer and poultry manure on fertility status of soil after growing maize. Samples of soil were taken for determination of various laboratory parameters before starting experiment (Table 1). After analysis, pots were filled with ten (10) $\mathrm{kg}$ soil and irrigated by ground water. Completely randomized design was applied to arrange the pots. Current experiment included 11 treatments and 3 replications.

\section{Treatments}

$\mathrm{T}_{1}=$ Chemical fertilizers at recommended rate; $\mathrm{T}_{2}=$ Chemical fertilizers at half recommended rate; $\mathrm{T}_{3}=$ Waste of poultry at the rate of $5 \mathrm{ton} / \mathrm{ha} ; \mathrm{T}_{4}=$ Waste of poultry at the rate of $7.5 \mathrm{ton} / \mathrm{ha} ; \mathrm{T}_{5}=$ Waste of poultry at the rate of 10 ton $/$ ha; $\mathrm{T}_{6}=\mathrm{T}_{1}+\mathrm{T}_{3} ; \mathrm{T}_{7}=\mathrm{T}_{1}+\mathrm{T}_{4} ; \mathrm{T}_{8}=$ $\mathrm{T}_{1}+\mathrm{T}_{5} ; \mathrm{T}_{9}=\mathrm{T}_{2}+\mathrm{T}_{3} ; \mathrm{T}_{10}=\mathrm{T}_{2}+\mathrm{T}_{4} ; \mathrm{T}_{11}=\mathrm{T}_{2}+\mathrm{T}_{5}$.

Maize variety (FM3) taken from Ayyub research institute was used as test crop. Poultry manure was applied according to treatments. Initially five seeds were sown per pot and after germination three plants were maintained. Crop was harvested at maturity. Post soil analysis was done by collecting samples from each pot. Urea, SSP and potassium sulfate were applied as sources for NPK. Recommended rate of NPK used in this study was $\mathrm{N}=225, \mathrm{P}_{2} \mathrm{O}_{5}=100$ and $\mathrm{K}_{2} \mathrm{O}=100 \mathrm{~kg} \mathrm{ha}^{-1}$, respectively.

\section{Analytical methods for soil analysis}

Analytical methods for laboratory determinations were used as given in Hand Book No. 60 of USDA (1969).

\section{Soil organic matter}

For organic matter determination Method 24 was used.

\section{Available phosphorus}

It was determined by Olsen's method (Tandon, 2011).

\section{Soluble potassium}

Soluble potassium was determined by (Method 11a).

\section{Statistical analysis}

Statistics 8.1 software was used for the statistical 
analysis. ANOVA was made for different parameters (Steel et al., 1997).

Table 1: Soil Characteristics used in experiment.

$\begin{array}{lll}\text { Characteristics } & \text { Unit } & \text { Value } \\ \text { Saturation percentage } & \% & \\ \mathrm{pH}_{\mathrm{s}} & - & 7.50 \\ \mathrm{EC}_{e} & \mathrm{dS} \mathrm{m}{ }^{-1} & 1.78 \\ \mathrm{CO}_{3} & \mathrm{me} \mathrm{L}^{-1} & 3.60 \\ \mathrm{HCO}_{3} & \mathrm{me} \mathrm{L}^{-1} & 6.30 \\ \mathrm{Cl} & \mathrm{me} \mathrm{\textrm {L } ^ { - 1 }} & 4.10 \\ \mathrm{SO}_{4} & \mathrm{me} \mathrm{\textrm {L } ^ { - 1 }} & 3.80 \\ \mathrm{Ca}+\mathrm{Mg} & \mathrm{me} \mathrm{\textrm {L } ^ { - 1 }} & 4.50 \\ \mathrm{Na} & \mathrm{me} \mathrm{L}^{-1} & 10.8 \\ \mathrm{SAR} & - & 7.20 \\ \mathrm{Sand} & \% & 45.1 \\ \mathrm{Silt} & \% & 26.8 \\ \text { Clay } & \% & 28.1 \\ \text { Textural class } & - & \text { Sandy clay loam }\end{array}$

\section{Results and Discussion}

\section{Plant height of maize}

Height of plants is the most important parameter that reflects crop productivity. All the treatments significantly affected this parameter of plant height (Figure 1). Extreme height of plants $(115 \mathrm{~cm})$ was observed in treatment $\mathrm{T}_{8}\left(\mathrm{~T}_{1}+\mathrm{T}_{5}\right)$. It significantly differed from $T_{7}(111.7 \mathrm{~cm})$ and $T_{11}(107.9 \mathrm{~cm})$. Inferior results were obtained in $\mathrm{T}_{3}$ (waste of poultry at the rate of 5 ton/ha) when linked by all other treatments. Kibria et al. (2013) observed that joined usage of poultry manure waste plus chemical fertilizer not only increased yield but also plant growth. The integration of poultry manure with inorganic source also improves the availability of nutrient to maize and its use efficiency (Ayeni and Adetunji, 2010).

\section{Total biomass of maize plants}

Biomass is vital parameter for fodder crops that indicate yield of crops. Total biomass of the maize crop was greatly affected by usage of poultry waste alone and in mixture with chemical fertilizers. Statistically all treatments showed significant difference on total biomass of maize crop (Figure 2). The treatment $\mathrm{T}_{3}$ remained inferior when compared with $\mathrm{T} 2$ in terms of statistics. Maximum biomass of maize $(64.34 \mathrm{~g})$ was produced by $\mathrm{T}_{8}\left(\mathrm{~T}_{1}+\mathrm{T}_{5}\right)$. Treatments $\mathrm{T}_{7}(58.67 \mathrm{~g})$ and $\mathrm{T}_{6}(55.67 \mathrm{~g})$ followed the treatment $\mathrm{T}_{8}$. Variances amongst these 03 treatments were non-significant statistically. Collective usage of poultry waste and mineral fertilizers improved maize growth and yield (Khaliq et al., 2004). Similarly, Boateng et al. (2006) observed an increase in maize biomass by addition of organic source like manure of poultry waste material.

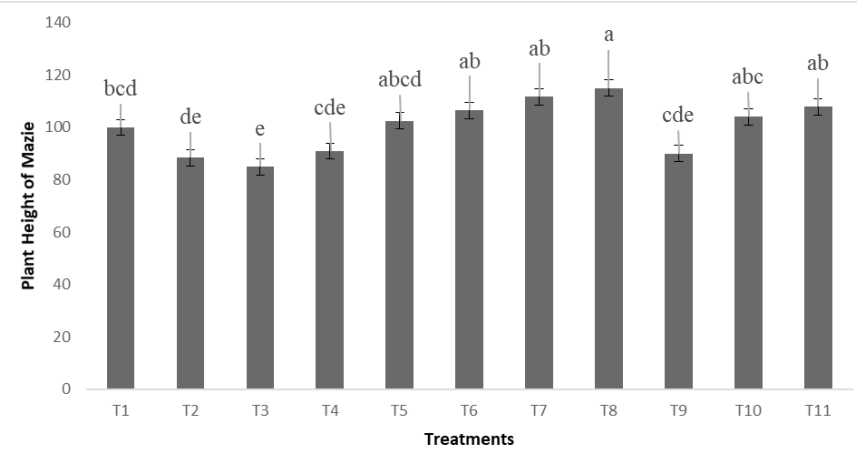

Figure 1: Combined effect of mineral fertilizer + poultry dung on maize height.

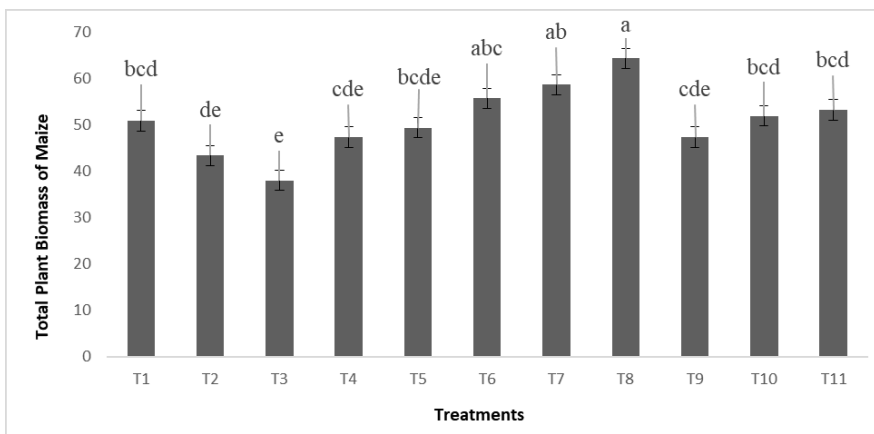

Figure 2: Combined effect of mineral fertilizer + poultry dung on maize biomass.

\section{Maize root length}

Plant roots are the most important part on which growth of plants depends. Poultry manure and inorganic fertilizer application to maize plant affected root length of maize plants (Figure 3). Maximum root length measured in treatment $\mathrm{T}_{8}\left(\mathrm{~T}_{1}+\mathrm{T}_{5}\right)$ was 27.08 $\mathrm{cm}$. The treatments $\mathrm{T}_{7}(24.58 \mathrm{~cm})$ and $\mathrm{T}_{11}(22.25 \mathrm{~cm})$ followed the $T_{8}$. The minimum root length $(11.66 \mathrm{~cm})$ was noted in treatment $T_{3}$. The treatments $T_{2}(12.5$ $\mathrm{cm})$ and $T_{4}(13.75 \mathrm{~cm})$ remained at par statistically. These outcomes were in accordance of the findings of Shah et al. (2007). They determined improved root length in maize when fertilized with poultry manure and inorganic nitrogen fertilizer.

\section{Organic matter in soil}

Organic matter has a significant part in soil fertility. Carbon-based manures are nutritious supplement used to increase soil organic matter. Almost all soil properties depend on organic content present in soil. Soil fertility was significantly exaggerated by 
the incorporation of carbon-based manures (Figure 4). The treatment $T_{2}$ remained most inferior where just organic form of nutrients was added. Maximum organic matter content was observed in treatment $\mathrm{T}_{8}$ (0.72\%). Treatment $\mathrm{T}_{8}$ significantly differs from $\mathrm{T}_{7}$ when compared in terms of statistics. The treatment $\mathrm{T}_{1}$ with a value of $1.78 \%$ organic matter was next to $T_{2}$.

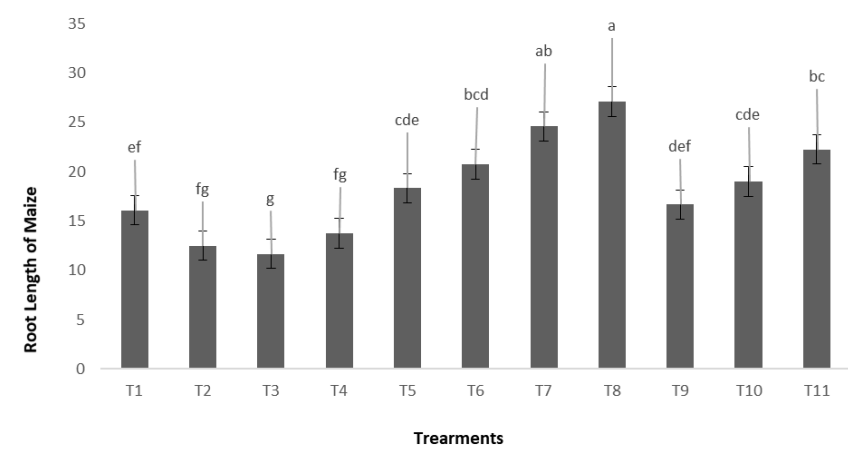

Figure 3: Combined effect of mineral fertilizer + poultry dung on maize root length.

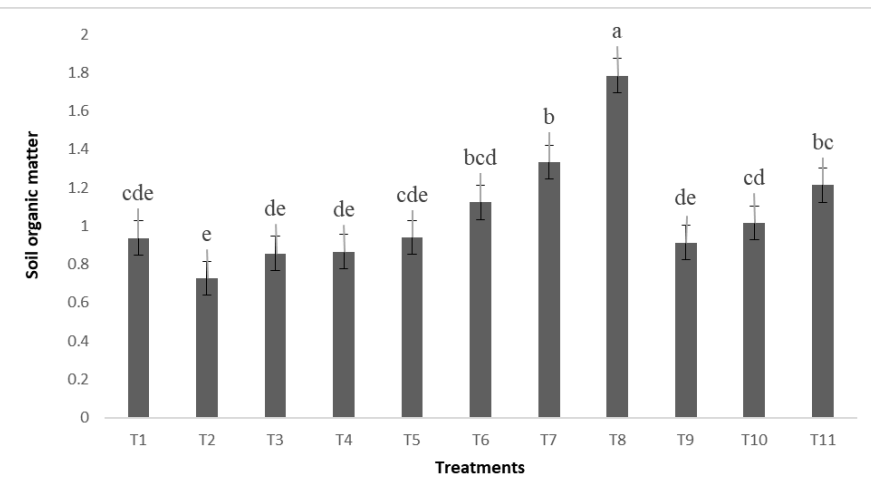

Figure 4: Combined effect of mineral fertilizer + poultry dung on soil organic matter.

Sarwar et al. (2008) revealed that incorporation of carbon-based manure with mineral fertilizers was a good technique to enhance fertility of soil. When carbon-based manure is used with mineral fertilizers, it enhanced its efficiency and productivity in sustainable agriculture. Addition of poultry manure increased nitrogen content in the soil. This content can be further increased by using chemical fertilizer along with poultry dung. Development, quality and produce of maize crop can be increased by using organic and inorganic sources of fertilizers (Boateng et al., 2006).

\section{Phosphorus in soil}

Phosphorus is $2^{\text {nd }}$ maximum plentiful element on earth surface. Its availability is highly dependent on soil $\mathrm{pH}$ and calcareousness. It is an important element required for plants growing. Phosphorus has a constitutional character in ATP molecules besides nucleic acid. It enhances crop maturity. Poultry manure is not only a good source of phosphorus but also increase availability of phosphorus in the soil. All the treatments significantly affect the phosphorus content of the soil (Figure 5). Extreme $\mathrm{P}$ concentration was noted in treatment $T_{8}$ (chemical fertilizers at recommended rate + waste of poultry at the rate of 10 ton/ha). Phosphorus concentration in $\mathrm{T}_{1}$ and $\mathrm{T}_{2}$ treatment was recorded as 8 and 5 ppm respectively. Minimum value of soil phosphorus was determined in $T_{2}$ where $1 / 2$ of recommended dose of chemical fertilizer was used. All other treatments significantly differ from each other. These discoveries were in line with conclusions of Friend et al. (2006). Similarly, McGrath et al. (2009) also noted that all types of soil properties (physical, chemical and biological) were upgraded by usage of poultry dung.

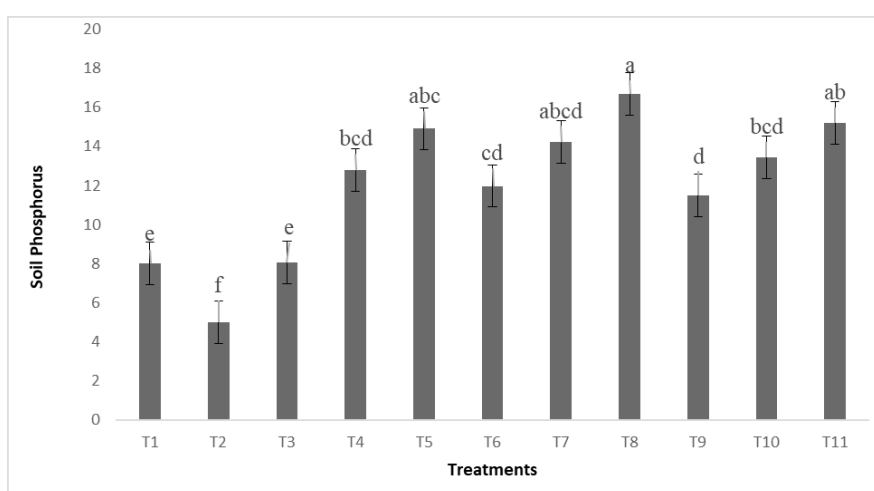

Figure 5: Combined effect of mineral fertilizer + poultry dung on soil phosphorus.

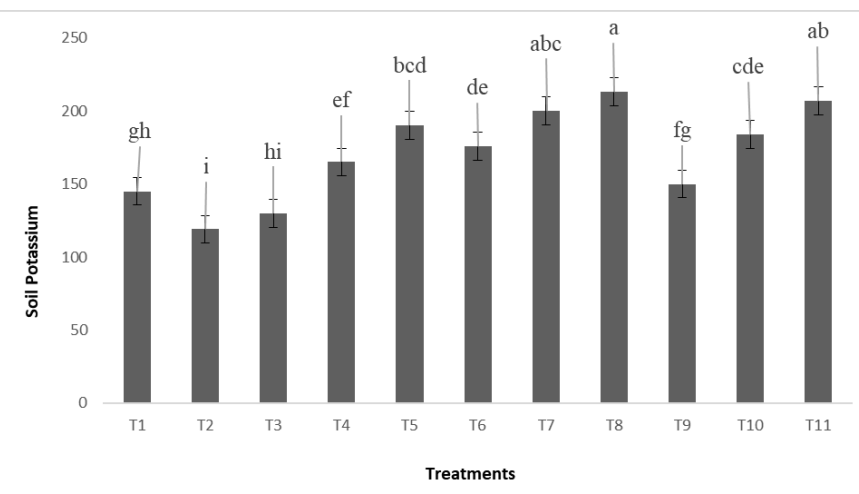

Figure 6: Combined effect of mineral fertilizer + poultry dung on soil potassium.

\section{Potassium in soil}

Potassium stands as an enzyme activator and third most abundant element. Soil potassium in experiment is significantly affected by all the treatments. Highest value of soil potassium was recorded in treatment $\mathrm{T}_{8}\left(\mathrm{~T}_{1}+\mathrm{T}_{5}\right)$ with a value of $213 \mathrm{ppm}$ (Figure 6). 
Whereas, minimum concentration was observed in treatment $\mathrm{T}_{2}$ (half recommended NPK) with a value of $119 \mathrm{ppm}$. Treatment $\mathrm{T}_{1}$ was next to $\mathrm{T}_{2}$ with value of $145 \mathrm{ppm}$. Both these treatments were significantly different. Likewise, $\mathrm{T}_{3}$ (waste of poultry at the rate of 5 ton/ha) and $\mathrm{T}_{4}$ (waste of poultry at the rate of 7.5 ton/ha) remained statistically significant. These results are supported by the observations of Guo and Song (2009). They observed an improvement in nutrient status of soil with the use of poultry dung.

\section{Conclusions and Recommendations}

It was concluded from current experiment that combined/integrated used of mineral fertilizers coupled with poultry dung at the rate of 10 ton/ ha remained most superior treatments to all others for boosting of maize yield and maintenance of soil fertility (organic matter, phosphorus and potassium status). Hence, it is recommended to farmers that they should integrate poultry dung or waste material with chemical fertilizers to boost up crop yield and maintenance of soil health.

\section{Novelty Statement}

Usage of poultry dung improve maize yield and maintains soil health.

\section{Author's Contribution}

Muhammad Fiyyaz: Conception and design of the work and conduction of experiment.

Ghulam Sarwar: Academic supervisor.

Noor-us-Sabah: Drafting and technical assistance.

Mukkram Ali Tahir: Co-supervision and technical assistance at every step.

Muhammad Aftab and Sarfraz Hussain: Interpretation of data and excel work for graphs making.

Muhammad Zeeshan Manzoor and Ayesha Zafar: Helped in lab. work and write up.

Imran Shehzad and Aneela Riaz: Statistical analysis and Proof reading and final editing.

\section{Conflict of interest}

The authors have declared no conflict of interest.

\section{References}

Anonymous, 2008. Agricultural Statistics of
Pakistan. Government of Pakistan, Ministry of Food, Agriculture and Livestock (Economic Wing), Islamabad.

Antil, R.S., 2012. Integrated plant nutrient supply for sustainable soil health and crop productivity. A. Kumar (Eds) vol. 3. Focus Global Reporter, 2012.

Ayeni, L. and M. Adetunji. 2010. Integrated application of poultry manure and mineral fertilizer on soil chemical properties, nutrient uptake, and yield and growth components of maize. Nat. Sci., 8(1): 60-67.

Boateng, S.A., J. Zickermann and M. Kornahrehs. 2006. Poultry manure effect on growth and yield of maize. J. Appl. Ecol., 9: 2006. https:// doi.org/10.4314/wajae.v9i1.45682

Chaudhary, D.P., S. Kumar and S. Langyan. 2014. Maize: Nutrition dynamics and novel uses. Springer New Delhi, Heidelberg, New York, Dordrecht, London. https://doi. org/10.1007/978-81-322-1623-0

Friend, A.L., S.D. Roberts, S.H. Schoenholtz, J.A. Mobley and P.D. Gerard. 2006. Poultry litter application to Loblolly pine forests: Growth and nutrient containment. J. Environ. Qual., 35: 837-848. https://doi.org/10.2134/ jeq2005.0244

GOP, 2015. Ministry of Food, Agriculture and Livestock (MINFAL), Govt. of Pakistan.

Gorttappech, A.H., A. Ghalavand, M.R. Ahmady and S.K. Mirnia. 2000. Effect of inorganic and organic fertilizer on quantitative and qualitative traits of different cultivars of sunflower (Hellianthus annus L.). Ir. J. Agric. Sci., 6(2): 85-104.

Guo,M. and W. Song. 2009. Nutrient value of alumtreated poultry litter for land application. Poult. Sci., 88: 1782-1792. https://doi.org/10.3382/ ps.2008-00404

Khaliq, T., T. Mahmood and A. Masood. 2004. Effectiveness of farmyard manure, poultry manure and nitrogen for corn (Zea mays) productivity. Int. J. Agric. Biol., 2: 260-263.

Kibria, M., N. Hossain, M. Ahammad and K. Osman. 2013. Effects of poultry manure, kitchen waste compost and NPK fertilizer on growth and yield of ladies finger. IOSR J. Environ. Sci., Toxicol. Food Technol., 2(6): 5560. https://doi.org/10.9790/2402-0265560

Korsaeth, A., T.M. Henriksen and L.R. Bakken. 2002. Temporal changes in mineralization 
and immobilization of $\mathrm{N}$ during degradation of plant material: Implications for the plant $\mathrm{N}$ supply and $\mathrm{N}$ losses. Soil Biol. Biochem., 34: 789-799. https://doi.org/10.1016/S00380717(02)00008-1

McGrath, S., R.O. Maguire, B.F. Tacy and J.H. Kike. 2009. Improving soil nutrition with poultry litter application in low input forage systems. Agron. J., 102: 48-54. https://doi. org/10.2134/agronj2009.0198

Mohanty, S., N.K. Paikaray and A.R. Rajan. 2006. Availability and uptake of phosphorus from organic manures in groundnut (Arachis hypogea L.) corn (Zea mays L.) sequence using radio tracer technique. Geoderma, 133(3): 225-230. https:// doi.org/10.1016/j.geoderma.2005.07.009

Oad, F.C., U.A. Buriro and S.K. Agha. 2004. Effect of organic and inorganic fertilizer application on maize fodder production. Asian J. Plant Sci., 3: 375-377. https://doi.org/10.3923/ ajps.2004.375.377

Prabhu, T., P. Narwadekar, A. Sannindranath and M. Rofi. 2003. Effect of integrated nutrient management on growth and yield of okra (Abelmoschus esculentus L. Moench) cv. Parbhani Kranti. Orissa J. Hortic., 31(1): 17-21.

Sabah, N.U., G. Sarwar, M.A. Tahir and S. Muhammad. 2016. Comparative efficiency of high (triple super phosphate) and low (rock phosphate) grade $\mathrm{P}$ nutrition source enriched with organic amendment in maize crop. Pak. J. Bot., 48(6): 2243-2248.

Sabah, N.U., G. Sarwar, M.A. Tahir and S. Muhammad.2018. Depicting the role of organic amendments for bio available phosphorus release from different sources of rock phosphate and uptake by maize crop. Pak. J. Bot., 50(1): 117-122.

Sabah, N.U., G. Sarwar, M.A. Tahir and S. Muhammad.2018. Evaluation of dewaxed filter cake press mud for $\mathrm{p}$-release from indigenous rock phosphate and its utilization by maize.
Pak. J. Agric. Sci., 55(2): 361-366.

Sarwar, G., 2005. Use of compost for crop production in Pakistan. Okologie und Umweltsicherung. 26/2005. Universität Kassel, Fachgebiet Landschaftsökologie und Naturschutz, Witzenhausen, Germany.

Sarwar, G., H. Schmeisky, N. Hussain, S. Muhammad, M. Ibrahim and E. Safdar. 2008. Improvement of soil physical and chemical properties with compost application in RiceWheat cropping system. Pak. J. Bot., 40(1): 275-282.

Sarwar, G., M.A. Malik, N.S. Sabah, M.A. Tahir, M. Aftab, M.Z. Manzoor and A. Zafar. 2020. Comparative efficiency of compost, farmyard manure and sesbania green manure to produce rice-wheat crops under salt stressed environmental conditions. J. Pure Appl. Agric., 5(3): 33-42.

Sarwar, G., N. Hussain, H. Schmeisky and S. Muhammad. 2007. Use of compost an environment friendly technology for enhancing rice-wheat production in Pakistan. Pak. J. Bot., 39(5): 1553-1558.

Shah, Z., Z. Shah, M. Tariq and M. Afzal. 2007. Response of maize to integrated use of compost and urea fertilizers. Sarhad J. Agric., 23(3): 667673.

Steel, R.G.D., J.H. Torrie and D.A. Dicky. 1997. Principles and procedures of statistics: A biometrical approach. $3^{\text {rd }}$ ed. McGraw-Hill Book Int. Co., Singapore.

Tandon, H.L.S., 2001. Methods of analysis of soils, plants, waters and fertilisers. Fertiliser Development and Consultation Organisation 204-204A Bhanot Corner, 1-2 Pamposh Enclave New Delhi-110048, India.

U.S. Salinity Laboratory Staff. 1969. Diagnosis and Improvements of saline and alkali soils. Handbook No. 60. USDA. U.S. Govt. Printing Office, Washington, DC, USA. 